\title{
Involvement of the trigeminal nerve secondary to GBM of the cerebellar peduncle - Atypical presentation in a single case
}

\author{
Sérgio Tadeu Fernandes ${ }^{1,2}$, José Ricardo Guimarães Toloi ${ }^{1}$, Pedro Paulo Thimoteo da Silva ${ }^{1}$ \\ Santa Casa de Jaú, São Paulo, SP, Brazil and Hospital Brigadeiro, São Paulo, SP, Brazil.
}

\begin{abstract}
Glioblastoma multiforme (GBM) is the most frequent and malignant glial tumour and mainly affects adults aged between 45 and 65 years. ${ }^{1,2}$ It typically occurs in the cerebral hemispheres, although other locations and related clinical manifestations are described in the literature. ${ }^{1,2}$ The clinical, neuroradiological, surgical and neuro-pathological findings are reported of a 44 year-old female patient, who appears to represent the first case of involvement of the trigeminal nerve secondary to infiltration by GBM of the cerebellar peduncle.
\end{abstract}

\section{KEYWORDS}

Trigeminal nerve, glioblastoma, case reports.

\section{RESUMO}

Comprometimento do nervo trigêmio secundário a GBM do pedúnculo cerebelar Apresentação atípica em um único caso

O glioblastoma multiforme (GBM) é o tumor mais maligno e frequente entre os tumores primários do sistema nervoso central (SNC), tendo sua maior prevalência em indivíduos com idade entre 45 e 65 anos. ${ }^{1,2}$ Ocorre tipicamente nos hemisférios cerebrais, no entanto outras localizações e manifestações clínicas relacionadas são descritas na literatura. ${ }^{1,2}$ Os achados clínicos, neurorradiológicos, cirúrgicos e neuropatológicos em um paciente do sexo feminino de 44 anos de idade estão descritos no presente relato, o qual aparenta ser o primeiro caso relatado de comprometimento do nervo trigêmeo secundário à infiltração neoplásica de um GBM do pedúnculo cerebelar.

\section{PALAVRAS-CHAVE}

Nervo trigêmeo, glioblastoma, relatos de casos.

1 Neurosurgeon at Santa Casa de Jaú, São Paulo, SP, Brazil.

2 Coordinator of the Division of Vascular Neurosurgery at the Hospital Brigadeiro, São Paulo, SP, Brazil. 


\section{Introduction}

Glioblastoma multiforme (GBM) is the most frequent and malignant glial tumour and mainly affects adults aged between 45 and 65 years. ${ }^{1,2}$ It typically occurs in the cerebral hemispheres, although other locations and related clinical manifestations are described in the literature. ${ }^{1,2}$ The clinical, neuro-radiological, surgical and neuro-pathological findings are reported of a 44 year-old female patient, who appears to represent the first case of involvement of the trigeminal nerve secondary to infiltration by GBM of the cerebellar peduncle.

\section{Case report}

A 44 year-old female patient was admitted to the service after being unable to move for two days due to continuous vertigo, uncontrolled nausea and vomiting, which showed little improvement with pharmacological therapy.

On examination the patient was confined to the bed, although conscious, oriented in time and space, active, and cooperative. Anaesthesia of the left side of the face was noted, with paresis of the ipsilateral masticatory muscles with no evidence of deviation of the mandible, and multidirectional nystagmus that worsened when the head was moved. No fine-motor deficits or alterations in motor coordination were noted.

The onset of symptoms occurred around sixty days prior to admission with the patient reporting only paresthesia of the left half of the face. At that point analysis of cerebro-spinal fluid (CSF) demonstrated normal levels of protein and glucose and the absence of pathological cells, while brain magnetic resonance images (MRI) revealed a lesion centred on the left middle cerebellar peduncle with extension to the root of the trigeminal nerve.

Among the diagnostic hypotheses considered at the service of origin was an inflammatory or demyelinating process. Corticosteroid therapy was initiated, reducing the signs and symptoms and slowing their evolution.

Considering the worsening clinical condition and the inefficacy of the therapy applied, a second MRI was carried out on admission, which demonstrated growth of the lesion and the maintenance of the radiological pattern (Figure 1A-D). The pre-operative diagnostic hypothesis was of an expansive process with a high grade of malignancy, and the decision was taken to perform surgical resection and biopsy.

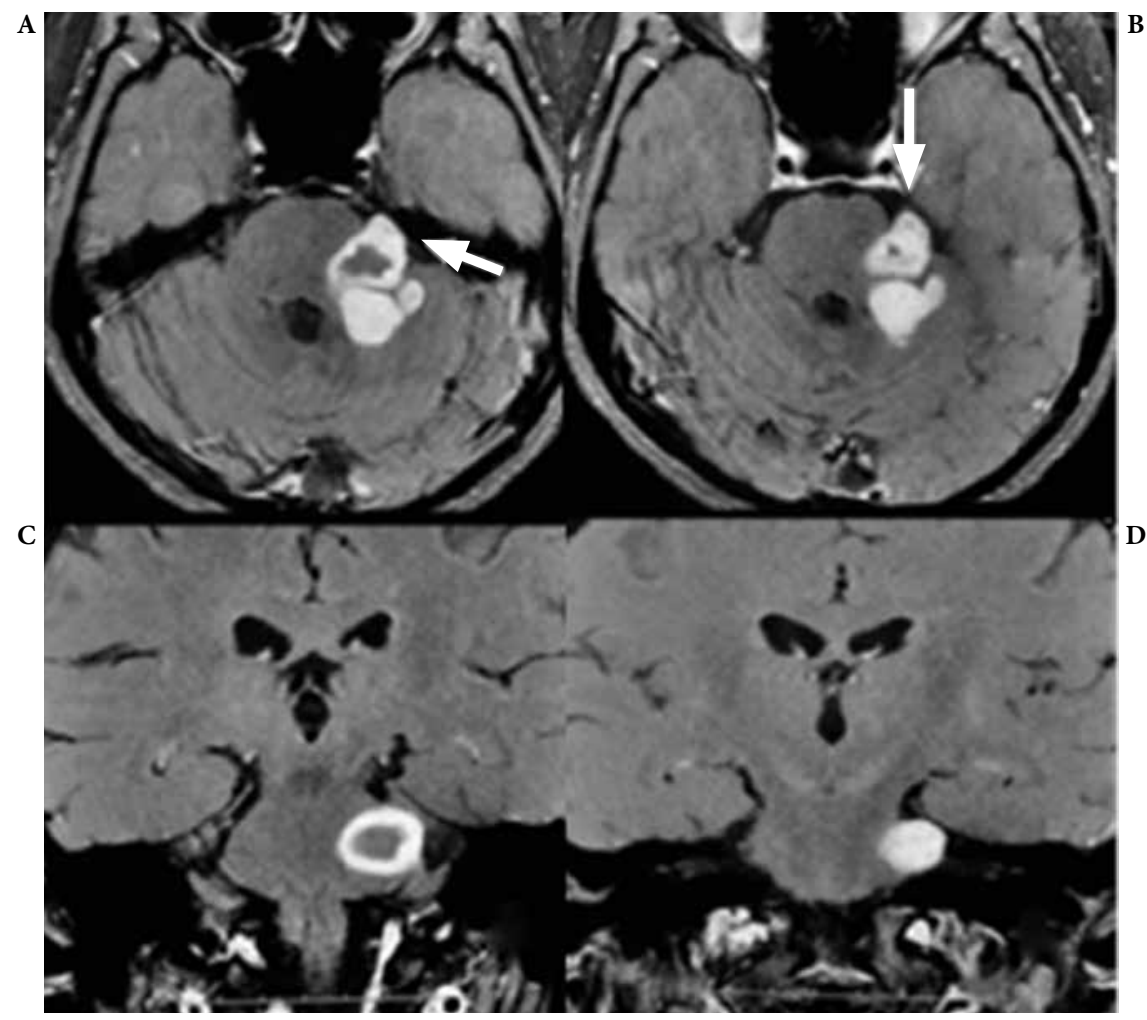

Figure 1 (A-D) - Brain magnetic resonance after injection of gadolinium. Note the heterogeneity of contrast enhancement and expansion of the lesion along the trajectory of the left trigeminal nerve (arrows), suggesting an exophytic lesion of the left cerebellar peduncle. (A,B) Axial images; $(C, D)$ coronal images. 
Surgical procedure and post-operative course: in a semi-seated position, through a left lateral sub-occipital craniectomy and skeletonisation of the ipsilateral transverse and sigmoid sinuses, ${ }^{3}$ via a left supra-cerebellar paravermal route broad access to the lesion and identification of the involvement of the trigeminal nerve was possible. The tumour was easily aspirated, grey in colour and poorly vascularised.

Following partial resection due to the peculiar location and altered parameters on neurophysiological monitoring, the patient was transferred to the Intensive Care Unit, where she remained for around thirty-six hours. Within the first twenty-four hours post-surgery the patient presented a significant improvement in symptomatology, managing to carry out personal care activities (hygiene and feeding) with minimum assistance. She was released from hospital on the fifth post-operative day, with minor cerebellar signs that restricted her to walking with assistance/ support, as well as the continued impact on the left trigeminal nerve.

Findings from pathological anatomy and immunohistochemistry were: histological examination revealed high-grade glial neoplasia with areas of necrosis and vascular proliferation suggestive of glioblastoma multiforme (GBM), confirmed by immunohistochemistry (raised Ki-67: > 30\%; GFAP +; p53 +; Vimentin +; S100 Protein + ).

Following anatomo-pathological and immunohistochemical confirmation of GBM, the patient was passed on to the Oncology service, where she is being followed up after sessions of radiotherapy and chemotherapy with temozolomide. The time of evolution from the surgical procedure to the most recent outpatient assessment is approximately eight months, without any further neurological morbidity.

\section{Discussion}

Involvement of the cranial nerves by neoplasias of the central nervous system (CNS) is known and has been described, mainly in compression syndromes and primary tumours such as schwannomas. ${ }^{4-6}$ Secondary changes relating to the trigeminal nerve are frequently observed in lesions of the petroclival region and the cavernous sinus, including meningiomas and aneurisms of the intracavernous internal carotid artery. ${ }^{?}$

The report presented here describes the first case, as far as we are aware, in which GBM clearly invaded and developed within the fifth cranial nerve. A case of GBM has been described which developed primarily in the oculomotor nerve with consequent effects on its functions. ${ }^{6}$ With regard to the origin of this peculiar tumour, several hypotheses may be considered, with it being most likely that the tumour arose as a glioma of the superficial portion of the cerebellar peduncle and close to the exit of the trigeminal nerve, with infiltration and secondary involvement of the latter.

The advent of MRI increased the precision with which the nature of intracranial lesions can be defined, as well as providing crucial information regarding the anatomy of the region impacted - an important element in the choice of approach in neurosurgery. In general, there is a reduction in signal intensity in $\mathrm{T} 1$ and an increase in T2, with heterogeneous annular highlighting after administration of the contrast medium. ${ }^{8}$ Occasionally, haemorrhaging can be seen in the centre of the lesion, peri-lesional vasogenic oedema, and imprecise limits, among other characteristics that suggest the diagnosis of neoplasia with a high grade of malignancy. ${ }^{8}$ The radiological findings available with current technology enable an early approach, which is imperative in the prognosis of CNS pathologies.

This report describes the first known example of a GBM with involvement of the trigeminal nerve and clinical presentation characterised by changes relating to the nerve and the cerebellar peduncle. While the precise origin of this tumour is uncertain, it is likely to have originated from glial cells of the cerebellar peduncle with secondary involvement of the nerve. Therefore, the case presented here adds GBM to the differential diagnosis of lesions with this location, and clinical and radiological presentation.

\section{Conflicts of interest}

The authors declare no conflicts of interest in this case report.

\section{References}

1. Russell DS, Rubinstein LJ. Pathology of tumors of the nervous system. $5^{\text {th }}$ ed. London: Edward Arnold; 1989. p. 219-47.

2. Zülch KJ, Bailey P, Rothballer AB, Olszewski J. Brain tumors. Their biology and pathology. $3^{\text {rd }}$ ed. Berlin: Springer-Verlag; 1986.

3. Quiñones-Hinojosa A, Chang EF, Lawton MT. The extended retrosigmoid approach: an alternative to radical cranial base approaches for posterior fossa lesions. Neurosurgery. 2006;58(4 Suppl 2):ONS-208-14.

4. Barat JL, Marchal JC, Bracard S, Auque J, Martin-Beuzart $\mathrm{S}$, Hepner H. [Neurinoma of the oculomotor nerves. Apropos of 2 cases]. Neurochirurgie. 1992;38(3):183-7. 
5. Celli P, Ferrante L, Acqui M, Mastronardi L, Fortuna A, Palma L. Neurinoma of the third, fourth, and sixth cranial nerves: a survey and report of a new fourth nerve case. Surg Neurol. 1992;38(3):216-24.

6. Reifenberger G, Boström J, Bettag M, Bock WJ, Wechsler W, Kepes JJ. Primary glioblastoma multiforme of the oculomotor nerve. Case report. J Neurosurg. 1996;84(6):1062-6.

7. Melaragno RF. Nervo trigêmeo In: Tolosa APM, Canelas HM. Propedêutica neurológica. 2a ed. São Paulo: Savier; 1971. p. $146-52$.
8. Kuroiwa T, Numaguchi Y, Rothman MI, Zoarski GH, Morikawa M, Zagardo MT, et al. Posterior fossa glioblastoma multiforme: MR findings. AJNR Am J Neuroradiol. 1995;16(3):583-9.

Correspondence address

Sérgio Tadeu Fernandes

Santa Casa de Jaú

Rua Riachuelo, 1073, Centro

17201-340 - Jaú, SP, Brazil

Telephone: (11) 2503-1010/(14) 3602-3233

E-mail: s_tadeu@outlook.com 